\title{
THE IMPACT OF DOMESTIC VIOLENCE ON THE PERSONALITY'S DEVELOPMENT OF THE CHILD
}

\section{Mitina S. V.}

\section{INTRODUCTION}

The actual problem of Ukrainian society is the overcoming and prevention of any manifestations of violence against children. The statistics show that the largest number of offenses against the person carries out precisely in the sphere of family relations, herewith about $95 \%$ of victims of domestic violence are women and children. Therefore, the problem of domestic violence often equates with the problem of domestic violence against women and minors. One third of children in Ukraine experience the domestic violence each year, it is important to accent that the childrenvictims of domestic violence commit the suicide 10 times more likely their peers. According to official data of the Ministry of Social Policy, $65 \%$ of children in Ukraine once abused, and $45 \%$ of children believe that they have experienced the psychological abuse ${ }^{1}$.

According to social studies, it is possible to state that the violence in the Ukrainian family is quite common: $44 \%$ of the Ukrainian population suffered from domestic violence throughout his life moreover, $30 \%$ of population is been abused in childhood. About half of those who is been abused as a child experienced the violence in adulthood. However, it is important to accent that the official statistics on domestic violence do not reflect the real picture, whereas the most of victims do not seek help from the police.

The situation of domestic violence greatly affects the physical and mental state of children. In $90 \%$ of cases children are witnesses by the scenes of violence, which causes them fear and frustration. Some children do not express any reaction to domestic violence, but as N.Y. Maximova notes, if there is violence, the psyche of the child always suffers. Moreover, in the case of maternal abuse, the child abuse is a possible consequence ${ }^{2}$.

\footnotetext{
${ }^{1}$ Державна доповідь про становище дітей в Україні «Реалізація конвенції ООН права дитини в Україні: досягнення, проблеми, перспективи» (за період 2009-2016 р.р.). Київ: Міністерство соціальної політики України, 2016. С. 51.

${ }^{2}$ Максимова Н.Ю. Психологія соціальної роботи із проблемними сім'ями. Київ: ВПЦ «Київський університет», 2017. С. 320.
} 
A significant part of families without state support is not able to fulfill their main functions, in particular to ensure the proper well-being and upbringing of the children. The worst thing is that the scope of domestic violence goes beyond the home: the children who suffer from domestic violence often commit the violent acts against their peers. The domestic violence, the child abuse leads to the formation of certain personality disorders, which provoke the deviant behavior in their future lives. Without overcoming this pernicious phenomenon, it is impossible to create conditions for the full development of the child's personality and to prevent further maladaptation of the minors.

\section{The causes of domestic violence against a child, its types and forms of manifestation}

The family violence is a complex phenomenon and has different forms and features, but the essence of the violence is the same. Domestic violence is an act that seeks to cause moral, physical or mental harm to another family member's health. Unlike most other types of violence, the domestic violence is always accompanied by coercion and control, and not only by physical but always psychological pressure. The most acute problem is domestic violence against children. The vulnerability of children to violence is explained by their physical, psychological and social immaturity, as well as their dependent position on adults.

It should be noted that the problem of domestic violence is multidisciplinary and various specialists study it. The representatives of different scientific schools and fields explain the violence, its causes, types and dynamics in accordance with their basic theoretical views. The scientists-lawyers study the problem of domestic violence in the context of the analysis of crimes committed in the sphere of family-domestic relations (A.G. Strelchenko, A.A. Sushchenko, L. Sukmanovsky and others). M.O. Mintz, A.M. Fesenko noted that domestic violence is a form of deviant behavior. The authors emphasize that, in addition to the aggressor, the victims of domestic violence are mainly women and minors ${ }^{3}$.

The punishment of the child, as a false method of correction of unwanted behavior, in a pedagogical context is considered by L. Begheza,

\footnotetext{
${ }^{3}$ Мінц М.О., Фесенко А.М. Насильство в сім’ї як фактор соціальних девіацій. Міжнародне періодичне наукове видання. 2013. № 2 (39). С. 17.
} 
V. Alekseeva, L.P. Melnik ${ }^{4}$. However, the research of C.I. Boltivets shows that the punishment of a child provokes only the behavior disorders, destructively affects the formation of personality and creates the basis for further maladaptation of minors ${ }^{5}$.

We use the sociological, psychological and socio-psychological conceptual approaches to explain the mechanisms of domestic violence.

The sociological approach defines the violence as a sociocultural conditionality, namely the violence is a stereotype of family relationships that is accepting in this population. Also, the domestic violence is influenced by social factors (socio-economic situation of the family, unemployment of parents, poor living conditions, etc.). L.M. Sukmanovskaya believes that domestic violence against women is a consequence of gender stereotypes and that the solution of this problem lies in the plane between such spheres of public life as culture, morality and law ${ }^{6}$.

In the aspect of psychological approach (I.A. Alekseeva, I.G. Novoselsky), the violence against a child is considered as a result of negative personal life experiences of parents, "trauma of childhood", alcoholism, psychopathology, or as a symptom of a dysfunctional family with inadequate stabilization of the family system. The negative attitudes toward a child may also be seen as the result of a destructive family interaction when, regardless of the presence or absence of specific psychosomatic characteristics or behavioral characteristics, the child risks being violent. From the psychological point of view, the motives for aggressive behavior are usually unconscious ${ }^{7}$.

The socio-psychological approach considers the domestic violence as a product of socialization, the reproduction of the model of behavior, the life experience that the child has received in the family (L.O. Kondratenko, N.Yu. Maksimova, K.L. Milyutina Yu.M. Udovenko and others). The scientists have shown that the children who have experienced the violence subconsciously seek to reproduce their life experiences in adulthood because they do not know another pattern of behavior. According to

\footnotetext{
${ }^{4}$ Мельник Л.П. Насильство над дітьми як соціально-педагогічна проблема. Корекційна та соціальна педагогіка і психологія. 2013. Ч. 2. С. 135-143.

5 Болтівець С. I. Домашне насильство як підгрунтя девіантної поведінки підлітка. Практична психологія та сочіальна робота. 2009. № 10. С. 38-39.

6 Сукмановська Л.М. Домашнє насильство: дослідження актуальної проблеми сьогодення. Юридичний Вестник. № 4. 2014. С. 217.

Алексеева И.А., Новосельский И.Г. Жестокое обращение с ребенком. Причины. Последствия. Помощь. Москва: Генезис, 2005. С. 195.
} 
T Goncharova, if parents were victims of abuse or neglected in childhood, they would use the same violent methods of education for their children ${ }^{8}$.

The domestic violence, abuse and neglect of children are manifested in different forms, have some dynamics of formation and varying degrees of expression. The families where children have abused are unequal in terms of social and material well-being, as well as the degree of emotional closeness between family members. In dysfunctional families the children are less protected from psychological trauma situations. The parents in such families are often try to reduce or conceal the violence against their child. On the basis of our research we can make conclusion, that the category of children, who has gone on the streets because of the parental abuse, are not only the children from socially disadvantaged families (57\% of our study sample), but also the children from affluent families herewith most of them (65\%) experienced the different types of violence in the family, it was a major factor of their going out ${ }^{9}$.

The violence against children in the family N.Yu. Maksimova has considered within four categories. Each of these categories of abuse can lead to physical or psychological harm to the child of varying degrees, the serious physical injury, or even death.

1. Neglect - the chronic inability or unwillingness of parents to meet the basic needs of the child in care appropriate to her age: in food, clothing, living space, medical care, education, protection and upbringing. This attitude is the result of adult irresponsibility. It varies from case when the parents leave the child alone at home for several hours while they work, to cases when the child is left unattended and the parents leave for the weekends or holidays. The worst case scenario is when parents are physically present but do not do what is necessary to ensure the health, safety, mental and physical development of the child. For example, when a child is starving or kept in a cold place, when he has not the seasonappropriate clothing, the opportunities to learn, etc. The child lives in a dangerous place: open electrical outlets, medicines, alcohol and other dangerous substances are in accessible places; hot pots, kettle, fire on stove, etc. The child who is harmed by all these dangers grows with

\footnotetext{
8 Гончарова Т.В. Насильство дітей у сім’ї: умови, причини й фактори виникнення. Соціальна педагогіка: теорія та практика. 2010. № 4. С. 47-53.

${ }^{9}$ Мітіна С.В. Соціальні чинники становлення особистості бездоглядних підлітків. Вісник Київського Національного університету імені Тараса Шевченка. Київ,2013. № 1 (7). С. 75.
} 
confidence that the world is threatening to her. It undermines the basic sense of security, forms a deep distrust of others and the world in general.

2. Psychological violence. It is the type of parents' behavior, which harms the child's personal development and self-esteem. The psychological abuse involves the verbal attacks such as constant criticism, humiliation, insults, ridicule, mocking, teasing, and refusing to listen to the child. The psychological violence also includes the inability of parents to show love and support and guidance necessary for personal growth and development of the child. The psychological violence can include the verbal and non-verbal violence, which will be without words at all - to make the victim feel humiliated or keep it in the atmosphere of fear using facial expressions, poses, sights, intonations.

3. Physical violence. This category includes the physical trauma of a child, not only when there are appropriate signs (bruises, wounds, fractures), but also such varieties of physical violence when the signs cannot be detected immediately because they manifest later (for example, internal organ damage, air obstruction etc).

4. Sexual violence. This category includes all kinds of sexual activities with children, as well as forcing children to have sex with one another or to watch adult sex. The child sexual abuse and sexual exploitation is one of the gravest violations of the rights of the child. The sexual assault and sexual exploitation are equal to torture by the amount of injuries inflicted. Even if a child perceives the sensual pleasure of adult action, it is still the sexual violence ${ }^{10}$.

Usually, the child victim suffers from several types of violence at the same time. It should be noted that psychological violence is an integral part of all types of violence. Much more dangerous is the situation when the elements of sexual, physical and psychological violence are combined, and the violent acts are accompanied by threats and intimidation by the abuser. The child suffers not only from the situation itself, but also from his own helplessness, inability to seek help, which leads to depression, suicide attempts and mental disorders (neuroses, psychotic reactions, etc.).

Summarizing aforesaid we can note that there is lot of causes that influence the manifestation of domestic violence against a child. However, whatever the reasons of the violence, it always causes the negative

\footnotetext{
${ }^{10}$ Максимова Н.Ю. Психологія соціальної роботи із проблемними сім’ями. Київ. ВПЦ «Київський університет», 2017. С. 321.
} 
consequences and raises a variety of problems, both social and psychological.

\section{The psychological characteristics of children-victims of family violence}

The psychological consequences of all forms of violence against the child are the formation of distrust in adults and the world at large. The child begins to be afraid to be active and independent in the study of the outside world, and this dramatically inhibits his mental and personal development.

The disturbances in the cognitive area are often found in disorders of the language. The neurotic stuttering may result because of child abuse. The children of school age have a decrease in concentration of attention because all thoughts of the child are occupied by traumatic experiences. The child keeps a close eye on everything that happens around, as if he is in constant danger. Moreover, the danger is not only external, but also internal, because of unwanted traumatic impressions, which always pop up in the mind ${ }^{11}$.

Recall that the basis of any form of violence is psychological, emotional deprivation, rejection, which cause harm to the development of the child's personality.

The children are brought up in the absence or limitation of parental care, which leads to the special deprivation of violations in the development of personality. I. Yaroslavtseva, depending on the specifics of the deprived development, has determined the full interruption of the child's communication with the parents, identified two levels of mental deprivation: general and partial. The general mental deprivation is formed under conditions of children's home, from birth or early childhood the children were deprived of parental care. In these cases, the specific development is characterized by a gross disproportion of all aspects of the development of the child's psyche. The partial mental deprivation is characterized by the mild disharmony of personal development. This disharmony is typical to the children and teenagers from dysfunctional families who are brought up in conditions of limited parental care and in the lack of emotional connection with their parents. These children and

\footnotetext{
${ }^{11}$ Бегеза Л., Алєксєєва В. Насильство над дитиною як чинник деструктивного впливу на формування іiі особистості. Сучасна икола Украӥни. 2011. № 9. С. 47-92.
} 
teenagers have the varied negative manifestations of the mental state, however, they are shallow and mosaic and may affect certain areas of personality development ${ }^{12}$.

$\mathrm{N}$.Yu. Maximova notes that the basis of all intrapersonal conflicts of the children from dysfunctional families is in the contradictory attitude towards parents: on the one hand, the child continues to love them, and on the other, the constant feeling of failure, the vainness of their hopes for appropriate attitude of parents causes painful emotional experiences. This contradiction keeps the child in constant tension, which leads to negative consequences. The personality development can further proceed in the following directions:

1) the occurrence of self-centeredness, when the child sees other people as the means to achieve their goals;

2) the rejection of "Self-image", the emergence of a "guilt complex", when the child devalues itself, feels incapable of anything, useless;

3 ) the formation of hypersociality, when the person tries to prove his whole life that he is worthy of respect ${ }^{13}$.

The children deprived of the positive influence of the family have the violations in the development of self-awareness, the inconsistency of "Self-image". The behavior of the child from an adictive family depends on the compulsive behavior of the parents, the "Self-image" is formed as the result of search for security, the desire to preserve their own identity. The desire to keep the attention of the parents on the child is established by the codependent behavior, which is expressed in the attempt to take on the solution of family problems, the denial of their own needs. The consequence is the devaluation of feelings and the inability to express them, the inability to establish the emotional intimacy, the instability of "Self-image".

A.A.Katsero's studies show that the teenagers from dysfunctional families have the contradictory ideas about themselves, they have the low differentiation of the "Self" characteristics: the images "Self-real", "Self-past", "Self-future" are close to "Self -ideal". The representation of the teenagers themselves in this form without the influence of functionally safe family doesn't provide socially approved behavior. The image of "Self

\footnotetext{
12 Ярославцева Н.В. Система мер по оптимальному жизнеустройству детей. Работник соииальной службы. 2003. № 2. С. 25-28.

${ }_{13}$ Максимова Н.Ю. Основи психології девіантної поведінки. Київ: ПЦ «Київський університет», 2008. $439 \mathrm{c}$.
} 
-ideal" is characterized by the positive direction, but it is inherent isolation from the "Self-real", the inconsistency of the "Self-image" actual experience. The "Self-image" of the neglected teenager is transformed under the influence of contradictions with the environment, self-defense becomes the leader in the structure of "Self-image" and turns into the means of self-affirmation. Therefore, the features of the "Self-image" structures are the indication of the person's possibility to adaptation to the social conditions of his life ${ }^{14}$.

The consequence of the deprivation of the child's need for parental care and love is a distorted development of self-awareness, expressed selfdoubt, low self-esteem. For explanation of the reasons for the inadequacy of self-esteem of neglected teenagers, we should recall the notion of "working model" (theory of attachment by J. Bowlby). The "working model" includes the model of oneself and of a loved one ("Self-Other"), while the perception of oneself is determined by perception of the object of attachment. The deep memory keeps the patterns of behavior with close people who are constantly repeated in interaction with others, determining the nature of the relationship in the dyad "Self-Other". The teenagers from dysfunctional families from early childhood are deprived of stable and emotionally balanced relations with their parents, which explains the inadequacy of their self-esteem.

The lack of significant adult and unconditional acceptance of the child, the limitations of parental care, makes it necessary to adapt in children the passive attitude to life. As the result, the neglected children do not form their own values and principles, however, the conformance of behavior develops, which contributes to the assimilation of antisocial norms and values in conditions of negative microsocium. Our studies indicate the transformation of the value-semantic sphere of the neglected teenagers, indicate their inconsistency, dependence on situational influences. There is the decrease in understanding of their present, past and future ${ }^{15}$.

The reaction to the situation of chronic family distress, violence, children form negativity or passive refusal to everything that is imposed on

14 Кацеро А.О.Структура та зміст „Я”-образу у бездоглядних підлітків. Актуальні проблеми психологї. Т. VII: зб. наук. працьь Ін-ту психологї ім. Г.С. Костюка АПН Украӥни. Київ, 2005. Вип. 3. C. $148-156$.

${ }^{15}$ Мітіна С.В. Психологічні чинники становлення особистості підлітків в умовах бездоглядності. Вісник післядипломної освіти: зб. наук. праць. Київ, 2012. Вип. 8 (21). С. 256-262. 
them as the habit to imitate any activity, at the same time, the ability for systematic efforts, which is important for independent living, is not formed. The teenagers becomes accustomed to the fact that nothing depends on him, resulting in the inability to plan his life, the low understanding of his ability to cope with the problems and life difficulties.

According to the concept of K. Horney, the child's early feelings, the rejection by parents, contributes to the growth of anxiety disorders, forms the basal hostility in the child. The emotional disorders, anxiety, fears are the necessary consequence of a situation of violence. The preschoolers have fears about fabulous creatures or an uncertain feeling of anxiety. One of the typical manifestation of a child's response to violence is sleep disturbance. It manifests in the form of night terrors with awakening, nocturnal enuresis, walking in a dream. Children and adolescents who have been abused, feel helpless and grief. The depressive emotional state characterized by crying, slowing down of mental processes, complaints about pain, which appears without the reason, can also be the consequence of violence ${ }^{16}$.

The study of K.L. Milutina, N.Yu. Maksimova showed that the internal contradiction between the intensification of teenager's negative emotions associated with the fact of domestic violence and the inability to express them in communication leads to the kind of "freezing" of emotions. At the same time, the development of the emotional sphere is inhibited, the formation of empathy does not occur, a peculiar emotional dullness is formed. This leads to the fact that in future adult life, such person is not only unable to express his feelings, but also shy person will try to avoid situations related to the emotional area of life ${ }^{17}$.

The violence in family negatively affects the homeostasis in the system of child - society on the level of behavioral manifestations. The state of constant threat forms the catastrophic cognitive model of the world and the need for barriers to interacting in the form of aggressive reactions, avoidance of contact and violation of social norms. The lack of positive communication with parents predetermines the development of inadequate communication with others, when protective situations of behavior dominate in conflict situations: the inability to constructively solve the

\footnotetext{
16 Чаплінська Л.В. Проблема психологічного насильства над дітьми дошкільного віку: причини, види та наслідки. Науковий вісник Мукачівського державного університету, 2015. Випуск 1 (1). С. 125-129.

17 Максимова Н.Ю., Мілютіна К.Л. Соціально-психологічні аспекти проблеми насильства. Київ: Комітет сприяння захисту прав дітей, 2003. 344 с.
} 
problem situation, outbreaks of aggression, and desire to shift responsibility to the others. The disadaptation of the children is manifested in the loss of social orientation of feelings, distrust of the social environment, social non-contact, inability to share their social roles, to establish friendly relations ${ }^{18}$.

$\mathrm{N}$. Yu. Maximova notes that depending on the peculiarities of the child's temperament, the disturbance of his emotional state due to domestic violence begins to manifest itself in the form of the following behavioral disorders:

- the children with a strong type of nervous system exhibit aggressive behavior directed at peers, namely they try to identify with the aggressor;

- the children with a weak type of nervous system feel intense anxiety even in safe situations, they complain about fears, are afraid of fairy-tale characters and real people. The children of this type often cry, avoid peer communication, and fear the strangers ${ }^{19}$.

Thus, violations that occur as a result of violence, affect all levels of human functioning. Abused children cease to trust people, because of this their circle of communication narrows, they become closed and hostile. One of the most important consequences is inadequate self-esteem, the lack of control over the impulsiveness, the decreased ability to express oneself, the lack of trust in people, depression. The domestic violence leads to persistent personal changes that impede the child's ability to realize himself in the future.

\section{The prevention of the violence in the family in relation to the minors}

In accordance to the Law of Ukraine, the prevention and counteraction to the violence in the family is defined as the system of measures aimed to the ending of domestic violence, to providing the assistance and protection to the victim, the compensation for damage, as well as the prosecution of offenders and the changing of their behavior ${ }^{20}$.

Although the prevention of domestic violence relates to the functions of the law enforcement agencies, working with the family which has this problem, is primarily the responsibility of the social worker and the

\footnotetext{
18 Болтівець С. I. Домашне насильство як підгрунтя девіантної поведінки підлітка. Практична психологія та соичіальна робота. 2009. № 10. С. 38-39.

${ }_{19}$ Максимова Н.Ю. Психологія соціальної роботи із проблемними сім'ями. Київ: ВПЦ «Київський університет», 2017. С. 329.

20 Закон України «Про запобігання та протидію домашньому насильству» від 7 грудня 2017 року № 2229-19 [Електронний ресурс]. Режим доступу: http://zakon3.rada.gov.ua/laws/show/2229-19
} 
psychologist. This is explained by the fact that usually the assistance to such family starts with the social intervention that occur after the receiving of the police reports. The social services focus on organizing the work with families who belong to the social risk group. Actually the certain system of correctional and rehabilitation work has been developed with the families which are in the difficult situations. This system includes the various state and public organizations, the multidisciplinary centers which, within their competence, carry out the measures to prevent and overcome the domestic violence.

The analysis of the literature on this issue shows that there are the different models of work with the families aimed at assisting of the children who are the victims of violence and preventing the domestic violence. The prevention of domestic violence involves the education of the parents to interact with their children at every stage of their lives, the prenatal support programs, and education of the young parents to proper care for their children. The purpose of other models of the care is timely detection of the child maltreatment. The third model directed to assist the victims of violence and minimize the risk of recurrence in the victim's future family. The fourth model work to strengthen the family and prevent the problems. The fifth - to help at-risk families - poor families, single mothers, young parents ${ }^{21}$.

In our opinion, in order to overcome the violence against children, it is important the organization of the system of the social and psychological assistance, which envisages the complex-differentiated approach taking into account the specifics of the family, the variety of domestic violence and is aimed both at providing assistance to the child, as well as to work with each family member, in order to further prevent of manifestation of domestic violence.

It should be noted that the effectiveness of assistance depends on the possibility of receiving it at any stage of the development of family relationships and the life of the child. Therefore, the organization of social and psychological work with the family to overcoming the violence should based on the following principles: accessibility, timeliness, completeness and confidentiality of care. In situations which pose a threat to the mental or physical health of the child, the crisis management is required. First of

\footnotetext{
21 Алексеева И.А. Жестокое обращение с ребенком. Причины. Последствия. Помощь. Москва: Генезис, 2005. С. 195.
} 
all, we have in mind the following types of violence: - the experiences of physical, psychological or sexual violence and their consequences; - the acute conflicts in the family; - the emotional and behavioral disorders in the child-parent relationship that provoke the child to leave the house.

Based on the analysis of the literature and the results of our own research, we believe that the most complete version of the structure of the crisis social and psychological assistance should include: - the crisis psychological emergency telephone; - the medical and psychological assistance; - the social and legal assistance; - the self-help groups, which aim to create the socio-therapeutic environment for teens ${ }^{22}$.

In Europe, children who have been subjected to violence in the family can be admitted to the temporary residence group at the regional crisis center. At the center, children continue to attend a regular school, and maintain relationships with their friends and parents, with whom work is also underway. The task of the Crisis Center - help the family to overcome the difficult circumstances ${ }^{23}$.

The effectiveness of social and psychological work with victims of domestic violence is ensured by the availability of various forms of assistance: the helpline, the individual counseling, the family counseling and the family psychotherapy. The use of different forms of work depends on the problem and the characteristics of the family.

In 2013, La Strada-Ukraine public organization created the National Children's Hotline, which operates around the clock on a toll-free number and receives the calls on violence and ill-treatment against children ${ }^{24}$. The emergency psychological crisis telephone allows to implement the main principle - the availability and timeliness of help. With acute problems, the immediate help is required, the sooner the child receives it, the less negative consequences it may be for him. It is also important to keep in mind that the motive for seeking the help from specialists, even with serious problems, is unstable, situationally conditioned, sometimes is ambivalent. For example, in cases of sexual abuse of a child, as a rule, the victim is distraught, suffering and seeking help, but at the same time fears

\footnotetext{
22 Мітіна С.В. Протидія насильству в сім’ї щодо неповнолітних. Науковий вісник Херсонського державного ун-ту. Серія «Психологічні науки». Херсон, 2015. № 2, С. 100-104.

${ }^{23}$ Domestic Violence Perpetrator Programs in Europe, Part I: A survey of Current Practice. International Journal of Offender Therapy and Comparative Criminology. 2012. № 10.

${ }^{24}$ Державна доповідь про становище дітей в Україні «Реалізація конвенції ООН права дитини в Україні: досягнення, проблеми, перспективи» (за період 2009-2016 р.р.). Київ: Міністерство соціальної політики України, 2016. С. 51.
} 
the condemnation because the child considers himself guilty of crimes, fear of the negative judgment or disbelief in the ability to change something. Therefore, it is important that the crisis management mode will be optimal and will provide the maximum availability for those who want help.

It is important to remember that the outsiders, neighbors, relatives, and friends are often approached about child victims of domestic violence. That's why it is very important the interaction between the specialists of different professions - psychologists, doctors, educators, social workers, lawyers. $t$ makes possible to solve the child's problems comprehensively and to see the situation from different points of view, including, if necessary, the organization of legal and medical assistance in other institutions, which increases the effectiveness of the results many times over.

To increase the protection and social and psychological rehabilitation of victims of domestic violence N.Yu. Maximova considers that it is advisable to create the interdisciplinary team, namely the group of specialists who work with the specific case at the stage of social intervention. The basis of the work of such interdisciplinary group is the process of considering of the case of violence. In the process of reviewing the case, each of the professional groups has two tasks:

1) to provide the services in their specialty to the family in which the violence took place;

2) to communicate and cooperate, exchange the information with representatives of other professional groups to provide services to this family ${ }^{25}$.

The various services that are part of the team operate within their respective roles and responsibilities. The cooperation with other services is, firstly, in the exchange of information, which obtainable by the course of work with the family, and secondly, in the definition and application of those roles of a particular service, that are need in this particular case.

The main advantages of the multidisciplinary approach are:

1. The increasing of the effect of communication between professionals of different specialties dealing with violence. The exchange of information provides the more comprehensive experience of situations in the specific families, enabling them to develop more effective methods of assistance for specific families and to gain experience to improve the level of assistance in general.

\footnotetext{
25 Максимова Н.Ю. Психологія соціальної роботи із проблемними сім’ями. Київ: ВПЦ «Київський університет», 2017. С. 334.
} 
2. The creating of information base to determine the best way to help the different types of families, depending on their characteristics.

3 . The increasing of the motivation of specialists in different specialties.

4. The deepening understanding of the problem and the variety of possible measures, which can be take to overcome it.

The confidentiality of appeals is the crucial condition for dealing with the crisis situations. This principle is very important in work with teenagers who are painfully concerned with the need to seek help for fear of "looking weak", unable to cope with their problems. The anonymity and confidentiality are particularly relevant dealing with victims of sexual abuse.

It should be noted that many adolescents who have experienced the domestic violence (especially those leading an asocial lifestyle, use drugs, etc.) have the negative experiences with adults and do not trust them. In this regard, it is important to create the unprofessional youth associations (self-help groups) that contribute to the organization of the sociotherapeutic environment. The main objectives of this group is the adaptation to the therapeutic process, the ease of teenagers' integration with the group of peers. Communication with the peers helps to reduce the fear, anxiety, distrust of psychologists and doctors, provides teens the information about opportunities of professional help. The example of creating of therapeutic environment for teens is the teenage volunteer helpline. The recruitment of volunteers to the training group to work on the telephone of trust of adolescent problems can be carried out by studentspsychologists, social workers, educators, doctors, which also gives them the opportunity to gain the practical skills. In times of crisis, talking to teenagers-peers on the helpline is often the intermediate for seeking professional help.

The main task of medical and psychological care is to carry out the individual, family and group psychotherapy, with the aim of minimizing the psychological consequences of violence and the working out of traumatic experiences. The abuse provokes many negative emotions: the pain, hurt, fear, anger. Herewith, the child may have the ambivalent feelings to the family member from whom he is experiencing the abuse. These experiences can interfere the spontaneous narration and verbalization of the problem. In this case, it is advisable to conduct the 
psychotherapy with the use of art-therapy, fairy-tale therapy and psychodrama, with which the child is able to respond to negative emotions.

We think that in addition to helping the child, in order to further prevent of domestic violence, the comprehensive work with the whole family is required, which provides the involvement of lawyers, social services, rehabilitation institutions and other social institutions. However, the work of the services should be organized taking into account the gravity of the violence and the degree of social disadvantage of the family, because its content is fundamentally different, for example, dealing with asocial families and parents who are dependent on alcohol, than working with externally prosperous families, but in which the violence against the child is also used. It should be emphasized that defining the forms of work with the parents, we do not mean the serious forms of violence (physical or sexual) that require the immediate isolation of the child and the criminal responsibility of the parents.

The most common type of violence in the socially disadvantaged families where parents abuse the alcohol is abusive treatment of the child, ignoring him or his needs. But despite family disadvantages, the placement in residential care is a strong traumatic factor for the children because of the loss of their parents, deprivation of their parental rights. That is why the main task of the work with alcohol addicted parents is to provide them the medical, psychological and social-legal assistance aimed to the treatment, motivation of parents to change their way of life, assistance in employment and further social support of the family.

The reasons of violence against the child in outwardly prosperous families are the conflicted relationships, the lack of emotional attachment, the mutual understanding between the family members. The social and psychological assistance is to organize the comprehensive work with the family to improve the conditions of family upbringing. In this case, it is advisable to conduct the family psychotherapy in order to normalize the relationships. In the case of physical abuse of a child, the social intervention and outreach to parents are required. If necessary, the offer to the child a temporary shelter, which will allow the parents to rethink their educational impact. In this case, it is advisable to start the family therapy course separately with the child and the parents, and finally with the participation of all family members. The refusal from the use of physical punishment is possible when the parents realize the consequences of their 
actions, the transformation of ideas about themselves at the cognitive and emotional levels, the reflection of their own childhood experience, getting help in solving their own problems ${ }^{26}$.

Based on the peculiarities of family relationships, the work with parents should be done according to the algorithm:

1. Overcoming mistrust, reaching an agreement for cooperation. So long as the parents attached to their children, the informing that the child will return to the family only after the parents change their behavior and their attitude to him will serve as an external motivation for cooperation.

2. Parenting negative emotions gives parents an opportunity to change their view of the situation, before constructively discussing the existing problems. Often, the physical punishment is caused by parents' inability to control their emotions. When we have the work with parents, it is advisable to apply the psychotherapeutic techniques that are aimed to forming the skills of self-control of aggressive impulses, techniques of self-regulation.

3. Helping parents overcome their own problems. Often, these parents themselves have suffered from childhood abuse and do not know the other methods of education. The lack of control over one's impulses is often associated with inadequately low self-esteem, self-doubt, and a negative self-concept. Aggressiveness in this case is a manifestation of powerlessness and correction of only its external manifestations is not enough, it is necessary the methods of overcoming the intrapersonal conflicts.

The general result of group psychotherapy is the change in family relationships, the acquisition of constructive ways of responding to family problems, which consequence is the restoration of emotional attachment and prevention of domestic violence. This can be done by the centers of social and psychological assistance to the family. The primary purpose of the psychologist is to assist the family members in identifying resources to overcome the crisis in the family. It may also be important for family members to develop the productive problem-solving skills and positive communication, for this purpose it is appropriated the communicative training.

Thus, the use of various forms of social and psychological assistance depends on the type of violence and the peculiarities and problems of each

\footnotetext{
${ }^{26}$ Удовенко Ю.М. Система служб соціально-психологічної підтрімки дітей- жертв насильства (вітчизняний та зарубіжний досвід). Актуальні проблеми психологї̈: зб. наук. праць Ін-ту психології ім. Г.С. Костюка АПН України. Київ, 2006. Т. VIII, вип. 2. С. 336-342.
} 
individual family. In the course of work, these forms can change and be combined: telephone counseling, eye counseling, family counseling, individual and group psychotherapy.

\section{CONCLUSIONS}

The analysis of the literature has shown that the domestic violence of the children are manifested in different forms, have some dynamics of formation and varying degrees of expression. The families where children have abused are unequal in terms of social and material well-being, as well as the degree of emotional closeness between family members. In dysfunctional families the children are less protected from psychological trauma situations. The domestic violence is a product of socialization, this is the production of the model of behavior, the life experience that the child has received in the family.

The violence against children in the family has considered within four categories: neglect, psychological violence, physical violence and sexual violence. It should be noted that the psychological violence is an integral part of all types of violence. The violence against children always causes the negative consequences and raises a variety of problems, both social and psychological. The psychological consequences of all forms of violence against the child are the emotional disorders, anxiety, fears, impulsiveness, inadequate self-esteem, lack of trust in people, hostility. Thus, the domestic violence leads to personal changes that impede the child's ability to realize himself in the future.

In our opinion, to solve problem of domestic violence, it is necessary to carry out a comprehensive social and psychological work with the whole family, which provides a differentiated approach, taking into account the specifics of the family and the type of domestic violence, and is aimed at providing assistance to the child, as well as to work with each family member. The effectiveness of social and psychological work is provided by various forms of assistance: helpline, individual counseling, family counseling and family psychotherapy. The use of different forms of work depends on the problem and the characteristics of the family. The solution of the problem of domestic violence is possible through the implementation of a comprehensively differentiated approach. 


\section{SUMMARY}

The actual socio-psychological problem of the domestic violence against the children is considered. On the basis of theoretical analysis of the psychological literature it was found that the violence in the family is a complex phenomenon and has different forms and features, but always accompanied by coercion and control, physical and psychological pressure. It was found that the most acute problem is domestic violence against children. It was considered that the violence against a child is as a result of negative personal life experiences of parents, "trauma of childhood", alcoholism, psychopathology, or as a symptom of the dysfunctional family. It is set that the violation occurs as a result of violence, which affects all levels of human functioning and raises many problems, both social and psychological. It was underlined that the violence hinders the mental and personality development of the child. It was concluded that to overcoming the violence against the children it's important such system of social and psychological assistance's structure, which provides the complex and differentiated approach aims to assure the child's assistance and to conduct the work with each member of the family for the purpose of further prevention of violence in the family.

\section{REFERENCES}

1. Алексеева И.А., Новосельский И.Г. Жестокое обращение с ребенком. Причины. Последствия. Помощь. Москва: Генезис, 2005. C. 195 .

2. Бегеза Л., Алєксєєва В. Насильство над дитиною як чинник деструктивного впливу на формування ії̈ особистості. Сучасна школа України. 2011. № 9. С. 47-92.

3. Болтівець C.I. Домашнє насильство як підгрунтя девіантної поведінки підлітка. Практична психологія та соціальна робота. 2009. № 10. С. 38-39.

4. Гончарова Т.В. Насильство дітей у сім’ї: умови, причини й фактори виникнення. Соціальна педагогіка: теорія та практика. 2010. № 4. С. 47-53.

5. Державна доповідь про становище дітей в Україні «Реалізація конвенції ООН права дитини в Україні: досягнення, проблеми, перспективи» (за період 2009-2016 р.р.). Київ: Міністерство соціальної політики України, 2016. С. 51. 
6. Domestic Violence Perpetrator Programs in Europe, Part I: A survey of Current Practice. International Journal of Offender Therapy and Comparative Criminology. 2012. № 10. P. 56.

7.Закон України "Про запобігання та протидію домашньому насильству” від 7 грудня 2017 року № 2229-19 [Електронний ресурс]. Режим доступу: http://zakon3.rada.gov.ua/laws/show/2229-19

8. Кондратенко Л.О. Рання діагностика жорстокого ставлення до дитини з боку рідних. Практична психологія та соціальна робота. 2009. № 10. С. 40-41.

9. Кацеро А.О. Структура та зміст «Я»-образу у бездоглядних підлітків. Актуальні проблеми психології: зб. наук. праџь Ін-ту психології ім. Г.С. Костюка АПН України. Київ, 2005. Вип. 3. С. 148-156.

10. Максимова Н.Ю., Мілютіна К.Л. Соціально-психологічні аспекти проблеми насильства. Київ: Комітет сприяння захисту прав дітей, 2003. 344 с.

11. Максимова Н.Ю. Основи психології девіантної поведінки. Київ: ПЦ «Київський університет», 2008. 439 с.

12. Максимова Н.Ю. Психологія соціальної роботи із проблемними сім'ями. Київ: ВПЦ «Київський університет», 2017. 467 с.

13. Мельник Л.П. Насильство над дітьми як соціальнопедагогічна проблема Корекиійна та соиіальна педагогіка $i$ психологія. 2013. Ч. 2. С. 135-143.

14. Мінц М.О., Фесенко А.М. Насильство в сім'ї як фактор соціальних девіацій. Міжнародне періодичне наукове видання. 2013. № 2 (39). С. 17-26.

15. Мітіна С.В. Психологічні чинники становлення особистості

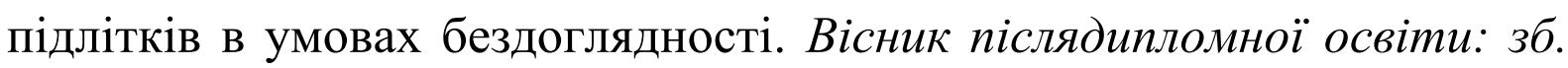
наук. пращь. Київ, 2012. Вип. 8 (21). С. 256-262.

16. Мітіна С.В. Соціальні чинники становлення особистості бездоглядних підлітків. Вісник Київького Наџіонального університету імені Тараса Шевченка. Київ, 2013. № 1 (7). С. 74-77.

17. Мітіна С.В. Протидія насильству в сім’ї щодо неповнолітних. Науковий вісник Херсонського державного ун-ту. Серія «Психологічні науки». Херсон, 2015. № 2, С. 100-104.

18. Стрельченко О.Г., Сущенко А.О. Адміністративно-правова протидія насильству в сім'ї як соціальна проблема в Україні. Ученье 
записки Таврического национального университета им. В.И. Вернадского. Серия «Юридические науки». Том 27 (66). 2014. № 1. С. 138-144.

19. Сукмановська Л.М. Домашнє насильство: дослідження актуальної проблеми сьогодення. Юридичний Вестник. № 4. 2014. C. 215-219.

20. Удовенко Ю.М. Система служб соціально-психологічної підтрімки дітей- жертв насильства (вітчизняний та зарубіжний досвід). Актуальні проблеми психології: зб. наук. праџь Ін-ту психології ім. Г.С. Костюка АПН України. Київ, 2006. Т. VIII, вип. 2. C. 336-342.

21. Чаплінська Л. В. Проблема психологічного насильства над дітьми дошкільного віку: причини, види та наслідки. Науковий вісник Мукачівського державного університету, 2015. Випуск 1 (1). C. $125-129$.

22. Ярославцева Н.В. Система мер по оптимальному жизнеустройству детей Работник социальной службы. 2003. № 2. С. 25-28.

\section{Information about the author: Mitina S. V.}

$\mathrm{PhD}$ of Psychology, Associate Professor, Associate Professor at the Department of Psychology and Pedagogy of the V. I. Vernadsky Taurida National University 33, Ivana Kydri str., Kyiv, 01042, Ukraine Researcher ID: G-7268-2017 ORCID: 0000-0001-9520-0272 